\title{
技術開発賞受賞の紹介
}

市街地における鉄道線路直下地下切替工法

\section{NEWLY INVENTED METHOD OF SWITCHING THE EXISTING TRACK TO THE NEW ONE RIGHT UNDER IN THE URBAN AREA}

\author{
赤荻康鿆* ・八方隆邦** \\ Yasusuke AKAOGI and Takakuni HAPPO
* 正会員 上学士 東京急行電鉄（株）交通事業本部管理部长 ( 150 啮谷区道玄坡 1-21-2)
**正会員 上学士 東宗急行奄鉄（株）交通事業本部上狢部士 木課拉

Keywords : newly invented method, right under the track, free from additional land, economical

\section{1.はじめに}

都市部の鉄道は, 輸送力の増強を要請される一方で, 踏切道での交通漇滞や交通事故等の都市機能を阻呈する 要因の解消を目指しており，これを㬰現するために自治 体，鉄道事業者によって道路と鉄道との立体交差化事業 が行われてきた。

鉄道立体交差工事は，一般に，現在線に沿って仮線路 用地を確保し、ここに一口線路を移し, 空いた既設線路 敷に新設構造物を造る仮線工法が採用されているが，近 年の地価高騰から用地取得が困難よなり, 事業用地を最 小限に抑える工法の研究，開発が行わ机てきた。 その結 果, 線路の直上, 直下に新設構造物を築造する工法が一 部採用されてきたが, 工事起・終点の線路切替部は, 作 業時問の制約等から仮線工法に頼らざるを得なかった。

今回行った直下地下切替工法は, 鉄道立体交差工事で 初めて“仮線を全く必要としない”線路切替を可能とし た.これは, 直上高架工法にも応用でき, 今後, 鉄道の 立体事業において, 事業費の軽減は勿論のこと, 工期の 短縮が図れ, 周辺住民の理解も得易くなる等, 事業の推 進に大いに役立つものと期待される.

\section{2.工法が実施された事業}

東急池上線と東京都都市計画街路 $26 \cdot 30$ 号線との逨 続立体交差化事業（写真参照）は, 当該地が都内有数の 住宅密集地区 (35000人 $\left./ \mathrm{km}^{2}\right)$ で沿線には側道もなく, 仮線用地確保に多大の労力, 侍問および費用が必要なこ とが予想されたため，その㬰施が色ぶまれていた。この ため, 用地必要面積を大幅に縮小する工法として, 中間 部では直下地下工法在採用すると共に, 起点部では一夜 で線路を地下線に切替える直下地下切替工法を開発し， 事業を夷施するに至った。なお，終点方線路切替部は，

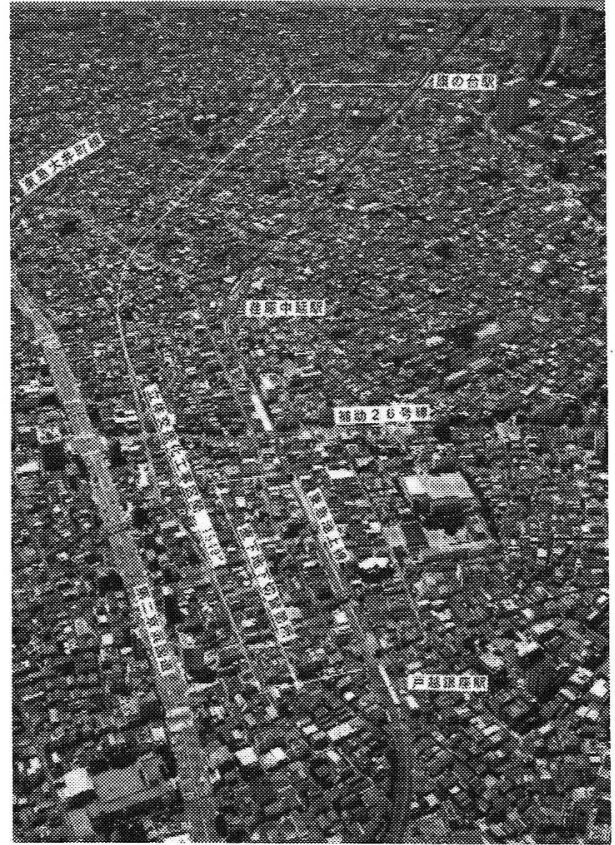

鉄道用地に余裕があったため，仮線工法を採用した。

\section{3. 工法開発にあたっての考え方}

工法の開発にあたっては，䬧存の器機を使用し，㓣意 工夫により行うこととした.

鉄道線路の直下地下切替工法とは，図一1に示す切替 区間の新線路に支障する線路仮受桁を，終・初電間の限 られた時問内に，安全かつ確実に撤去する工法である。 線路切替後の旧線路上が空くことに着目し，撤去した桁 の大部分はここに移される(縦取部).その移動方法上 しては, 縦取部の仮受桁に台車を装着し, 両側に敷設し 
(1)

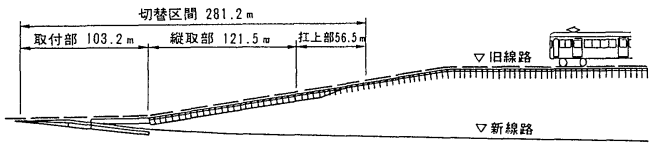

切替区問は，仮受桁の撤去方法により，3ブロック化する.

(2)

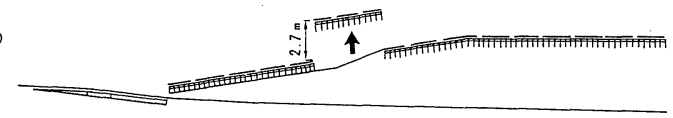

取付部は，調整材を撤去する．扛上部の仮受晰は吊り上げる.

(3)

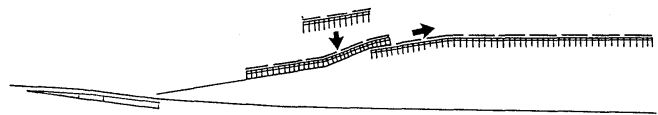

台車にセットされてある縦取部の第 1 回引出しを行う.

(4)

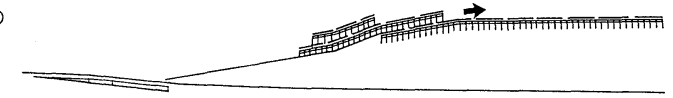

縦取部を所定の位置まで移動した後, 扛上部を降下, 縦取部上に固定 する。

(5)

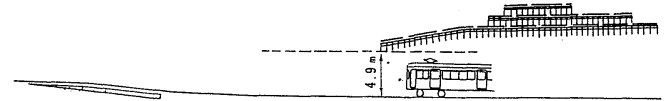

扛上部を載せた縦取部は, 踏切道に支障のない位置まで移動する.

図一1 工法施工要領

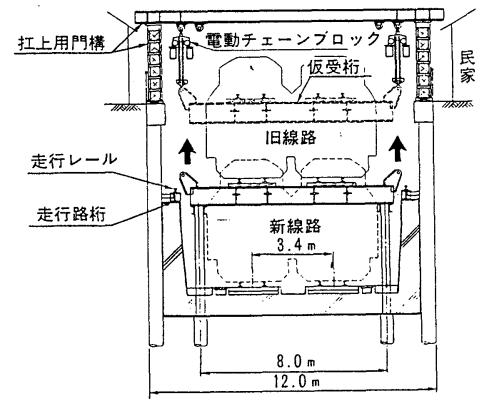

図一2 門構設 備

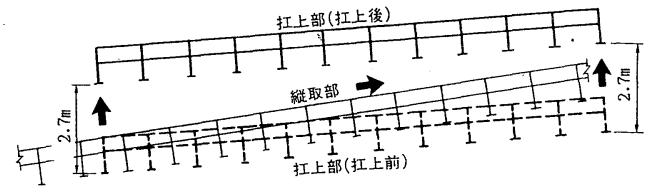

図-3 扛上 量

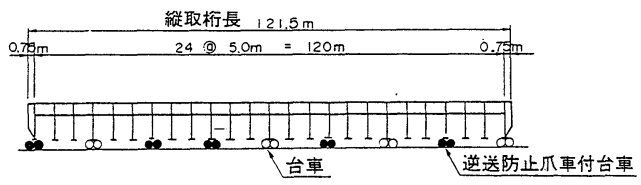

図-4 台車配置
た走行レール上を走らせる. このとき, 走行レールが仮 受桁下から旧線路上に渭付く区間の仮受桁（扛上部）が 縦取部移動に支障する。 そのため，これを一旦扛上し， 縦取部を移動させたあと, その上に降下させて一緒に撤 去する. この方法では, 切替区間の大量の仮受桁を短時 間に, 安全かつ容易に撤去することができる。 また, 取 付部については, 事前作業により旧線路下に調整材を挿 入し, 切替当夜これを撤去降下して, 新線路に転用でき る構造とする. 以上のように, 作業内容に合わせて切替 区間を分割し，作業の単純化をはかることで, 本工法が 可能となった.

\section{4. 直下地下切替工法}

\section{（1）扛上部切替工（延長 $56.5 \mathrm{~m}$ )}

この区間は，本工法のポイントとなった部分である. 扛上桁は走行レールの摺付区間で, 12 本の横桁から構 成され, 全重量は $110 \mathrm{t}$ である。これが, 縦取部移動に 支障することから一旦扛上し, 縦取部の第 1 回移動後に, その上に降下して一緒に撤去する.

a) 扛上設備について

扛上荷重は, 横桁 1 本当り最大で $5.5 \mathrm{t}$ と小さいこと から, (1) 軽量で操作が容易, (2) 扛上・降下速度が迅速, (3)リ一ス機があり経済的，の3つの条件を満足する, 容量 $10 \mathrm{t}$, 揚程 $6 \mathrm{~m}$ の電動チェーンブロックを各横析に
設置する(図一2).

チェーンブロックは, 集中制御で同時作動し，速度差 が生じた場合，個別制御に切替えられる配線とする．事 前作業で建築限界外に設置し, 切替当夜は電車線に関係 なく, 終電後ただちに作業できる構造とする.

b）扛上および降下量

扛上量は仮受桁, 台車, 旧線路亡走行レールの勾配差, および余裕高を考慮し，合わせて作業の単純化をはかる ため, 一様に $2.7 \mathrm{~m}$ とする（図一3）. 降下についても, 同時同量とし，順次縦取部仮受析に固定する.

\section{（2）縦取部切替工（延長 $121.5 \mathrm{~m}$ )}

本工法の核となる部分で，この区間を現在線上の補助 26 号線先（移動距離約 $250 \mathrm{~m}$ ）までウインチにより引 き上げる.

a）横桁支承部および走行台車

縦取部は縦断勾配になじむ構造とし，25 本の横桁と これらを継ぐ縦桁とで構成され，走行台車を片側に 9 台 装着し, 8 径間連続桁として縦移動する(図一4). 勾配 中を走行するため 5 台には逆行防止の爪車を装備する. 切替当夜は, 午前 0 時より電車を最徐行 $(15 \mathrm{~km} / \mathrm{h})$ させ, 横桁支承ボルトの一部を取外し, 終電作業の軽減をはか る.

b）縦取用走行レール

両側に敷設する走行レールは，本線から転用した 50 


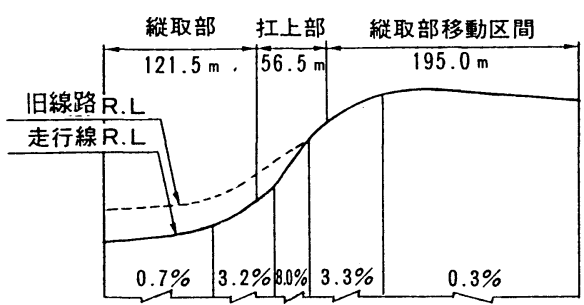

図一5縦取用走行路縦断線形

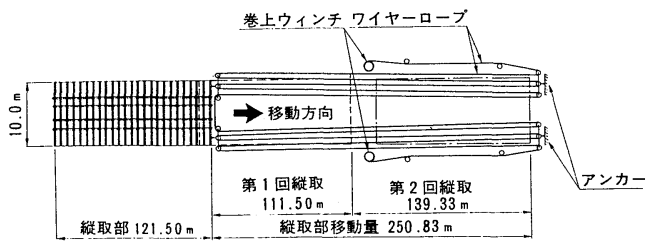

図一6 ワイヤロープ繰込

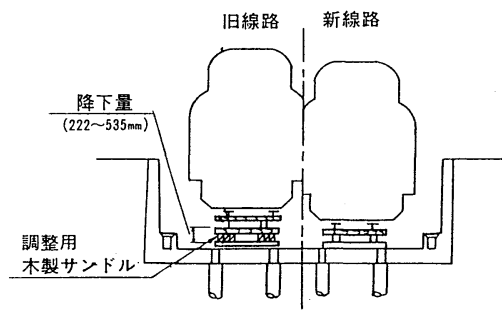

図一7 取付部施工要領

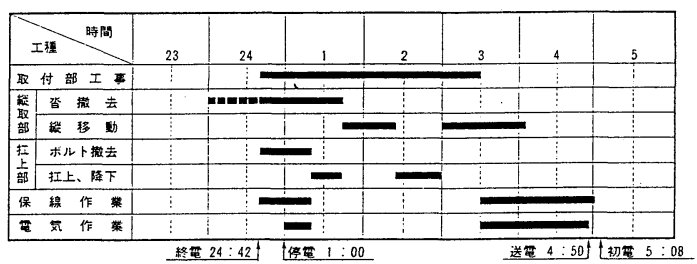

図一8 概略時間工程

\section{5. 経 済 性}

本切替工事費は，軌道工事費および電気工事費を含め 約 10 億円である. 一方仮線工法の場合，当該箇所では 土木工事費が多いことから 14 億円になり，さらに 4000 $\mathrm{m}^{2}$ の用地一時借用費, 60 軒分の家屋補償費が必要亡な る.このほか用地交渉等に費やされる膨大な時間と，住 民感情に与える様々な影響を勘案すれば本工法の優位性 に疑いの余地はない。

\section{6. おわりに}

本切替工事は，平成元年 3 月 18 日から 19 日の終・初 電間で無事終了した (図一8)。この技術を応用し, 東横 線大倉山一菊名駅間立体交差化事業において，工事区間 $780 \mathrm{~m}$ をまったく仮線を使用せず，地上から高架に線路 切替を行う工事を本年 10 月に予定しており，その他に も用地確保が困難と思われる数箇所でも現在計画中であ る.

(1991.7. 31 受付） 